\title{
ORIGIN AND DISPERSAL OF THE ALEWIFE, $A L O S A$ PSEUDOHARENGUS, AND THE GIZZARD SHAD, DOROSOMA CEPEDIANUM, IN THE GREAT LAKES
}

\author{
ROBERT Rush MiLler \\ Museum of Zoology, University of Michigan \\ Ann Arbor, Michigan
}

\begin{abstract}
It is possible that the alewife is native to Lake Ontario and the gizzard shad to Lake Erie, although conclusive evidence for this is lacking. There appear to be no records of the alewife from Lake Ontario prior to 1873, after the lake had been stocked with American shad. That species may still orcur in Lake Ontario occasionally. A tabular comparison of these species is given to facilitate identification. The alewife is referred to the genus Alosa (rather than Pomolobus) because no reliable characteristics are available to distinguish the species of these two groups.

Wilmot recorded a herring-like fish (not the American shad) from Lake Ontario about 1837 which probably was the gizzard shad, though it may have been the alewife. The first record of gizzard shad in Lake Ontario is for 1913, but the species was repoited from Lake Erie in 1848, 18 years after the completion of the first canal to connect Lake Erie and the Ohio River. It is hypothesized that the gizzard shad entered Lake Erie in pre-Columbian times during a warm-dry period.

A chronological record of the appearance of alewives in the upper Great Lakes show's the first specimen reported from Lake Erie was taken in 1931, Lake Huron 1933, Lake Michigan 1949, and Lake Superior 1954; actual dates of first appearance in each lake are unknown, but the species obviously moved from Lake Erie to the other lakes via Detroit River and Lake St. Clair. The alewife did not become abundant in Lake Erie or Lake Huron until around 1950 or in Lake Michigan until about 1956; it is widely distributed but not yet abundant in Lake Superior. The phenomenal increase in abundance and spreading of the alewife may be correlated with the upset in population balance by the sea lamprey; catch statistics for the alewife and shallow water cisco (Coregonus artedii) from South Bay, Lake Huron, suggest a direst or indirect causal relationship during 1954-1956.

The gizzard shad does not occur north of lower New York Harbor (and there only rarely) on the Atlantic slope, although it has been reported from New Brunswick, where it was probably misidentified for the alewife. Its inland range has been extended by canal connections and perhaps it reached Lake Erie in this way; it definitely entered Lake Michigan through the Chicago River canal. A reference in 1874 to the "saw-belly" from the Great Lakes undoubtedly represents the gizzard shad, also known by that name. The species has evidently spread to Lake Ontario and the vicinity of Quebec by moving through the Welland Canal, and to Lake Huron via the Detroit River and Lake St. Clair. The first specimen known to be taken in Lake Michigan was caught on October 13. 1953, west of Muskegon, Michigan; another was taken near Garv, Indiana, rn November 2, 1953. The gizzard shad has not been reported from Lake Superior where cold, deep water may prohibit its establishment. It has on occasion gained some commercial importance in Lakes Erie and Huron, where
\end{abstract}


31,600 pounds valued at $\$ 930$ were taken in 1949 . The gizzard shad may have been aided in expanding northward by the warming climatic trend of the past half century.

The two species, particularly the alewife, are steadily increasing in abundance and methods of utilizing this new resource should be devised.

\section{INTRODUCTION}

Three species of the herring family, Clupeidae, which is predominantly marine, have been reported from the Great Lakes drainage. The American shad, Alosa sapidissima Wilson, has been listed as native to Lake Ontario (e.g., by Hubbs and Lagler, 1947, p. 34), although others claim that it first appeared there when planted by the U.S. Fish Commission in the 1870's (Smith, 1892, Pp. 193-194; Evermann and Kendall, 1902, p. 213). The species was last recorded from Lake Ontario in 1931, but it occurs in the lower Ottawa River and stragglers may occasionally reach the lake (Radforth, 1944, pp. 94-95). As detailed below, the alewife, Alosa pseudobarengus (Wilson), may have penetrated the Great Lakes drainage from the St. Lawrence River as far as Lake Ontario. It has been able to surmount the barrier of Niagara Falls by passing through the Welland Canal into Lake Erie, from which it has spread throughout the Great Lakes. The gizzard shad, Dorosoma cepedianum (LeSueur), probably entered the Great Lakes drainage naturally from the Mississippi River basin via Lake Erie and then moved eastward into Lake Ontario. Its recent occurrence in Lake Michigan, on the other hand, seems clearly the result of immigration through the Chicago River canal; it is unknown in Lake Superior or in the northern parts of Lake Huron and Lake Michigan.

Because fishery biologists and others have difficulty in distinguishing these three species, some of the distinctive external characters are indicated (Table 1) in order to facilitate identification, particularly of young fish. Leim (1924, p. 227, figs. 28-31) gave additional characters that distinguish shad from alewives, including photographs of early life-history stages. An adult gizzard shad (unless injured) is easily recognized by the greatly lengthened last dorsal ray, as well as by the small, inferior mouth and deep body. The position of the dorsal fin, relative length of the anal fin, and comparative size of the upper jaw provide field characters for distinguishing smaller specimens of the three species. Vertebral counts do not overlap between the alewife and the shad or between the gizzard shad and the shad. As Graham (1956, p. 20) has shown, populations of the alewife from Lake Ontario have fewer vertebrae than do those of Atlantic coastal streams. 
TABLE 1.-Comparison between three species of berrings reported from the Great Lakes drainage

\begin{tabular}{|c|c|c|c|}
\hline Character & American shad' & Alewife $^{2}$ & Gizzard shad"s \\
\hline Last ray of dorsal fin... & Not modified & Not modified & $\begin{array}{l}\text { Moditied into a long } \\
\text { filament (inconspicuous } \\
\text { or absent in young) }\end{array}$ \\
\hline Origin of dorsal fin & $\begin{array}{l}\text { Well before insertion of } \\
\text { pelvic fins }\end{array}$ & $\begin{array}{l}\text { Well before insertion of } \\
\text { pelvic fins }\end{array}$ & $\begin{array}{l}\text { Over or behind insertion } \\
\text { of pelvic fins }\end{array}$ \\
\hline 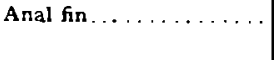 & $\begin{array}{l}\text { Relatively short, with } \\
18-24 \text { rays }\end{array}$ & Short, with $15-20$ rays & $\begin{array}{l}\text { Relatively long, with } \\
25-36 \text { rays }\end{array}$ \\
\hline Ventral scutes. . & $\begin{array}{l}\text { Typically } 22+16=38 \\
\text { (range. } 34-39 \text { ) }\end{array}$ & $\begin{array}{l}\text { Typically } 19+14=\mathbf{3 3} \\
\text { (range, 32-37) }\end{array}$ & $\begin{array}{l}\text { Typically 18 }+12=30 \\
\text { (range. 27-32) }\end{array}$ \\
\hline Longitudinal scale rows. & $52-64$ & $45-54$ & $52-70$ \\
\hline $\begin{array}{l}\text { Vertebrae (including } \\
\text { hypural) } \ldots \ldots \ldots \ldots\end{array}$ & $52-60$ & $47-50$ & $48-51$ \\
\hline Upper jaw..... & $\begin{array}{l}\text { Long, slender. its tip } \\
\text { reaching posteriorly to } \\
\text { middle of pupil in young } \\
(25 \mathrm{~mm} \text {. T.L.) and to } \\
\text { beyond eye in adult; } \\
\text { no notch }\end{array}$ & $\begin{array}{l}\text { Shorter and wider, its } \\
\text { tip reaching to front of } \\
\text { pupil in young and to } \\
\text { rear of pupil in adult: } \\
\text { no notch }\end{array}$ & $\begin{array}{l}\text { Short and moderately } \\
\text { wide, its tip scarcely } \\
\text { reaching front of eye in } \\
\text { young and front of pupil } \\
\text { in adult: a slight notch } \\
\text { (indentation) along ven- } \\
\text { tral margin in young. } \\
\text { becoming a deep notch } \\
\text { in adult }\end{array}$ \\
\hline Lower jaw.. & $\begin{array}{l}\text { Strong, longer than up- } \\
\text { per jaw, not fitting into } \\
\text { notch in upper jaw }\end{array}$ & $\begin{array}{l}\text { Strong, projecting be- } \\
\text { yond upper jaw, not } \\
\text { fitting into notch in } \\
\text { upper jaw }\end{array}$ & $\begin{array}{l}\text { Relatively weak, equal } \\
\text { to (young) or shorter } \\
\text { than upper jaw, fitting } \\
\text { into notch in upper jaw }\end{array}$ \\
\hline Mouth. & Terminal & Terminal & Subterminal to inferior \\
\hline Gillrakers. & $\begin{array}{l}\text { Long. slender, about } \\
25-75 \text { on lower limb in } \\
\text { young to adult }\end{array}$ & $\begin{array}{l}\text { Long, slender, about } \\
20-40 \text { on lower limb in } \\
\text { young to adult }\end{array}$ & $\begin{array}{l}\text { Very long, fine, close-set. } \\
\text { about } 90-275 \text { on lower } \\
\text { limb in young to adult }\end{array}$ \\
\hline
\end{tabular}

'Vertebral counts taken from Vladykov and Wallace (1938); number of anal rays in part from Leim (1924, p. 224); gillraker counts approximated from Hildebrand and Schroeder (1928, p. 94).

"Counts original, based on Great Lakes and Ontario material only, except for gillraker number which is modified from Hildebrand and Schroeder (1928, p. 89). Leim (1924, p. 206) recorded a variation of 46 to 51 vertebrae in Atlantic Coast alewives.

'All counts taken from Miller (1950) except number of gillrakers, which is original. 
ALEWIFE

The scientific name of the alewife is generally given as Pomolobus pseudoharengus (Wilson). However, Hildebrand and Schroeder (1928, p. 93) indicated that Pomolobus and Alosa are scarcely distinct and Bailey, Winn and Smith (1954, p. 118) gave further reasons why it seems best to unite them. No clear-cut morphological characters have been proposed to distinguish as a group the species usually placed in Pomolobus from those assigned to Alosa. Moreover, the name Pomolobus probably rests on uncertain nomencatural grounds, for it may be questioned seriously whether Rafinesque's description of $P$. chrysocbloris (type species of $P_{O}$ molobus) is based on this genus and species or on the Ohio shad, Alosa alabamae obiensis Evermann (S. F. Hildebrand, unpublished manuscript on the Clupeidae of the Western North Atlantic). Use of Alosa, the older of the two generic names, thercfore seems preferable.

There is no conclusive evidence that the alewife occurs naturally in Lake Ontario. Bean (1884, p. 589) and others believed it was introduced there by mistake in the 1870's when shad were planted by the U.S. Fish Commission. This has been denied (see Smith, 1892, p. 188), but evidence for nativity is weak since there appear to be neither specimens nor records of the species from Lake Ontario prior to 1873. The possibility that alewives did reach this lake from the St. Lawrence River should not be dismissed, however. Radforth (1944, p. 96) felt that they may have entered Lake Ontario during the invasion of the Champlain Sea, in the later stages of the glacial history of the Great Lakes. Toner (1934) pointed out that its presence in certain lakes whose outlets pass over barrier falls in Frontenac and Leeds counties, eastern Ontario, disproves the claim that the alewife was planted in Lake Ontario. Possibly the species reached its limits of toleration in Lake Ontario and in favorable seasons was able to establish sizable populations which were decimated during inimical years, when presumably only the hardiest individuals persisted. Since around 1890 , the alewife has intermittently appeared in Lake Ontario in almost incredible numbers, as noted during periodic summer dic-offs (Graham, 1956, p. 21). Whether such comparative abundance reflects recency of introduction is problematical.

The historical appearance of the alewife in the upper Great Lakes, as evidenced by captures known to the author, is given in chronological order (Table 2). The first specimen was taken in Lake Erie in 1931, in Lake Huron in 1933, in Lake Michigan in 1949 and in Lake Superior in 1954. This clearly establishes the sequence of its invasion of these lakes but the dates of first appearance in each lake are not known. As Dr. M. B. Trautman pointed out (in litt.), there must have been thousands of alewives in Lake Erie in 1931 before one could be caught in a net. Nevertheless, the species apparently did not really become abundant there until about 1950, although commercial fishermen caught alewives infrequently, in Ohio waters, after 1940, and there were similar reports from the Cana- 
TABLE 2.- Spread of the alewife in the upper Greal Lakes

\begin{tabular}{|c|c|c|}
\hline Date & Locality & Remarks' \\
\hline Sept. 23, 1931... & $\begin{array}{l}\text { L. Erie, at E. end off } \\
\text { Nanticoke, Ont. }\end{array}$ & Adult, $78 / 4$ in. long (Dymond, 1932). \\
\hline Mar. 28. $1933 \ldots$ & $\begin{array}{l}\text { L. Huron. } 12 \text { mi. E. of } \\
\text { Outer Duck Id.. Ont. }\end{array}$ & $\begin{array}{l}\text { Adult, from about } 70 \text { fathoms; others } \\
\text { reported (MacKay, 1934). }\end{array}$ \\
\hline
\end{tabular}

April 15, 1935 ... $\quad$ L. Huron, $40 \mathrm{mi}$. from Rogers Cily, Mich.

Dec. 26-31, 1940 L. Erie, off South Bass Id., Ohio

Dec. $27,1942 \ldots . \quad$ L. Erie, near Vermillion and Lorain, Ohio

May 5, 1949 .... L. Michigan, W. of S. Manitou Id.. Mich.

Mar. 20, 19512... L. Michigan, off Whitehall. $14 \mathrm{mi}$. SW. of Montague, Mich.

Mar, 12, 1952,... L. Michigan, $10 \mathrm{mi}$. ENE. of Milwaukee, Wisc.

July 13, 1953 .... L. Erie, on beach $W$. of Colchester, Ont.

July 14, 1953 .

L. Erie, South Bass Id., Ohio

Dec. $22,1953^{3} \ldots$ L. Michigan, $12 \mathrm{mi}$. WNW of South Haven, Mich.

Sept. $25,1954 \ldots$

L. Superior, off Pendill's Cr. Chippewa Co.. Mich.

Nov.. 1954

L. Superior, Chequamegon Bay. off Long Id., Wisc.

June $1 \& 14,1955$

L. Superior, Whitefish Bay about $1 \mathrm{mi}$. $N$. of mouth of Tahquamenon R., Mich.

June 3, $1955 \ldots$ L. Huron drainage: Ocqueoc $\mathbf{R}$. Weir near Rogers City, Mich.

June 10, 1955 ... L. Superior, Whitefish Bay, Mich.

June 11, 1955

L. Michigan, East Bay of Grand Traverse Bay, Mich.

Sept. 14, 1955 ...

L. Huron, along shore in the Les Cheneaux Channels.

Oct. 17 and Nov. 12, 1955 Mackinac Co., Mich.

Feb. 13, 1956

L. Superior. Gros Cap area near Sault St. Marie, Ont.

L. Superior, off Two Harbors, Minn.

Adult, $188 \mathrm{~mm}$. S. L., from 70 falhoms: UMMZ No. 109109 (Van Oosten, 193S).

Adule, 9 in. T. L. taken in gillnet by K. H. Doan (Trautman. 1957).

Two adults taken in gillnet by fishermen (Trautman, 1957).

Adult, $176 \mathrm{~mm}$. S. L., from 60 fathoms. Charles Anderson; UMMZ No. 157215.

Adult. $197 \mathrm{~mm}$. S. L., from 60 fathoms, James Grover; UMMZ No. 160969 (see The Fisherman, Vol. 19, No. 5. 1951, p. 6).

Adult. 177 mm. S. L.. Frank Miller; UMMZ No. 162861.

Young-of-the-year taken with gizzard shad (Langlois, 1954, p. 207).

Young-of-the year (Langlois, 1954, p. 207)

Adults, 180 and $188 \mathrm{~mm}$. S. L., from 32 fathoms, Chris Jensen; UMMZ No. 166514.

Adult, $168 \mathrm{~mm}$. S. L., Robert Gordon; UMMZ No. 167872.

Adult, $164 \mathrm{~mm}$. S. L., obtained by Russell Daly; UMMZ No. 167945.

Adults, 162 and $175 \mathrm{~mm}$. S. L.. from pound net. Ernest L. Pomeroy.

Adults, 179 and $182 \mathrm{~mm}$. S. L., Albert E. Hall, Jr.; UMMZ No. 169062.

Adult, $197 \mathrm{~mm}$. S. L., sent in by L. R. Anderson.

19 juveniles, $55-76 \mathrm{~mm}$. S. L., bait dealer for Stanley Lievense; UMMZ No. 170945.

Fingerlings, about 2 in. T. L., bait dealer: ident. by L. R. Anderson.

Adult male $(210 \mathrm{~mm}$. T. L.) and adult female $(27,3 \mathrm{~mm}$. T. L.), ident. by K. H. Loftus and W. B. Scott; ROM No. 18157 (male).

Adule from herring net. Adolph Ojard; ident. by John G. Hale and Samuel Eddy. 
TABLE 2 -Continued

\begin{tabular}{|c|c|c|}
\hline Date & Locality & Remarks ${ }^{l}$ \\
\hline March, 1956 & $\begin{array}{l}\text { L. Superior, off Knife R., } \\
\text { Minn. }\end{array}$ & $\begin{array}{l}\text { Adult taken by Ivar Pederson; ident. by } \\
\text { John G. Hale. }\end{array}$ \\
\hline June 6, 1956 & $\begin{array}{l}\text { L. Superior, at mouth of Blind } \\
\text { Sucker R., Luce Co., Mich. }\end{array}$ & $\begin{array}{l}\text { Adult, } 93 / 2 \text { in. long. caught by George } \\
\text { McGary; } 2 \text { other adults also taken. } \\
\text { Ident. by } L \text {. R. Anderson. }\end{array}$ \\
\hline July 31, 1956 . & $\begin{array}{l}\text { L. Superior, Split Rock R. } \\
\text { area, Minn. }\end{array}$ & $\begin{array}{l}\text { Adult. } 161 \mathrm{~mm} \text {. S. L.. from herring net. } \\
\text { Ragnivald Sve. }\end{array}$ \\
\hline Aug. $31,1956 \ldots$ & $\begin{array}{l}\text { L. Superior, off Shaganance Id. } \\
\text { (near entrance to Black Bay). } \\
\text { Ont. }\end{array}$ & $\begin{array}{l}\text { Adult male, } 166 \mathrm{~mm} \text {. S. L., taken by } \\
\text { Melville Gerow; ident. by R. A. Ryder. }\end{array}$ \\
\hline Sept. 10, $1956^{2}$. & $\begin{array}{l}\text { L. Michigan, East Bay of } \\
\text { Grand Traverse Bay at } \\
\text { O-at-ka Beach, Mich. }\end{array}$ & $\begin{array}{l}341 \text { postlarvae to young, } 19-40 \mathrm{~mm} . \mathrm{S} \text {. L., } \\
\text { taken in minnow seine for Stanley Lievense: } \\
\text { UMMZ No. } 171308 \text {. }\end{array}$ \\
\hline Nov. $5,1956 \ldots$ & $\begin{array}{l}\text { L. Superior, Keweenaw Bay. } 1 \mathrm{mi} \text {. } \\
\text { off town of same name. Mich. }\end{array}$ & $\begin{array}{l}\text { Adult, } 181 \mathrm{~mm} \text {. S. L., from surface gillnet } \\
\text { over } 17 \text { tathoms, taken by Uno Weideman. }\end{array}$ \\
\hline
\end{tabular}

AAbbreviations are: S.L. standard length: T.L., total length; UMMZ, University of Michigan Museum of Zoology: ROM, Royal Ontario Museum.

2Approximate date.

'On April 24. May 10, and Oct. 20, 1954. 3 more aduits were taken in 32-50 fathoms by Mr. Jensen from the same general area; UMMZ No. 167702 .

dian waters of Lake Erie. "After 1950 the young and adults [alewives] were sufficiently numerous so that they were distributed rather regularly throughout Lake Erie. In December, 1954, they clogged the gill and fyke nets in the vicinity of Conneaut, Ohio, following a bad storm" (Trautman, in litt., Dec. 20, 1956). This information is supported by Dr. W. B. Scott who wrote (in litt., March 5, 1954) that ". . . in the last four or five years the alewife has definitely increased in numbers in Lake Erie." The Welland Canal has been available for this highly migratory species since 1829 , and yet we have no knowledge of its occurrence in Lake Erie until 1931 (or of the equally migratory sea lamprey before 1921).

The rather sensational increase in abundance and spread of the alewife during the past decade has probably resulted from a number of changes particularly favorable to this species. Important modifications in the complex interrelationships of the native fauna have been brought about by the sea lamprey, Pelromyzon marinus, and these disturbances may have influenced the change in alewife abundance. We do not yet have, however, sufficient biological information to be able to draw conclusions on this problem. The lake herring and alewife may compete for food and space at some stage in their life cycles since the adults rely heavily on inimal 
plankton. Locally, as at South Bay (Table 3), Saginaw Bay and Green Bay (information from Stanford $\mathrm{H}$. Smith), the alewife populations have recently increased greatly while the lake herring "stocks have decreased. Possibly, newly metamorphosed lampreys migrating across these bays to deeper water have helped to reduce the lake herrings; or, the decrease (particularly noteworthy in these bays in 1954, 1955, and 1956) may be a result of normal population fluctuation. That it has occurred simultaneously in the three bays, however, suggests some degree of causal relationship, direct or indirect, between the alewife, lake herring and lamprey (and possibly other species).

The alewife is now abundant in many parts of Lake Huron and Lake Michigan. During the period May 6, 1954, to March 10, 1955, when the U. S. Fish and Wildlife Service research vessel M/V CISCO made thirteen cruises in the southern part of Lake Michigan (mostly south of a line joining Milwaukee and Grand Haven, but north to a line joining Manitowoc and Ludington), no alewives were caught. On the other hand, during nine similar cruises in the northern half of Lake Michigan, over the period May 10 to November 12, 1955, 21 alewives were taken from 10 stations. Nevertheless, by late 1953 the alewife had moved as far southward in Lake Michigan as the vicinity of South Haven (Table 2, item 11). Moreover, in a memorandum dated January 2, 1957, Max A. Hunt (District Fisheries Supervisor, Plainwell, Michigan) reported that "Commercial fishermen, fishing out of Saugatuck, report the alewife is being caught in their "chub" nets in up to 43 fathoms of water. There have been 200300 fish taken in a single lift. The fishermen are complaining about the alewife fouling their nets." Saugatuck is about 20 miles north of South Haven and well within the southern half of Lake Michigan.

The author is indebted to Leonard S. Joeris for the following information on the alewife in the Green Bay area of Lake Michigan. The first indication of spawning was noted in October, 1953, when two or three schools of small alewives were present in the carp-holding ponds near Duck Creek, Wisconsin (at the southern tip of Green Bay). Additional reliabl: reports of schools of young were received in the early fall of 1954 and

TABLE 3.-Calch of alewife and lake berring in Soush Bay, Lake Huron, Onfario (all fish taken in $1 \frac{1 / 2}{2}$ inch mesh five-pound nets fished in same location)

\begin{tabular}{|c|c|c|c|}
\hline Year & Pounds alewife & Pounds herring & Number of lifts \\
\hline 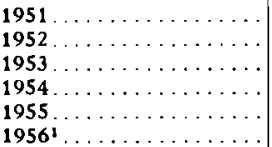 & $\begin{array}{l}0.2 \text { (1 fish) } \\
1.0 \text { (5 fish) } \\
6.0 \text { ( } 51 \text { fish) } \\
2,316 \\
16.302 \\
22,428\end{array}$ & $\begin{array}{r}36,018 \\
14,119 \\
12,625 \\
8,731 \\
4,841 \\
3,476\end{array}$ & $\begin{array}{r}175 \\
163 \\
65 \\
97 \\
86 \\
93\end{array}$ \\
\hline
\end{tabular}

'Figures for 1956 are provisional, subject to checking, but fina! figures could vary onjy a few pounds from those given. 
1955. The number of adults has increased yearly from a single individual in 1952 to common occurrence by 1955 in all herring pound nets-yet not in sufficient numbers to causc difficulty for the fishermen. By the spring of 1956, however, fishermen in the Ellison Bay and Gills Rock area (on the eastern side of Green Bay) were becoming quite concerned by the continuing increase of the alewife. A steady increase in numbers has also occurred for the gillnet fishery along the northern part of Green Bay and Lake Michigan.

Alewives are now abundant in the Saginaw Bay area of Lake Huron. For example, during operations of the CISCO over the period May 3 to October 25, 1953, 6 of 9 cruises caught this species. While trawling in a very shallow area near the southwest end of the Bay, about 6,000 alewives, 1.5 to 3.0 inches long, were taken in a 35 -foot trawl in one 5-minute bottom tow, and 8,500 were caught in a 5-minute tow just off the bottom. Over 50 percent of all fishes caught in trawling operations by the CISCO were alewives (information from Stanford H. Smith).

Records up to the fall of 1956 suggest that the alewife may not yet have established itself in numbers in Lake Superior although it has rapidly dispersed there. The CISCO ran nine cruises on the lake during May 3 to October 25, 1953, and took no alewives, although their nets were fished in some of the regions from which the species was obtained soon thereafter (Table 2.)

Van Oosten (1935) felt that the alewife probably entered Lake Huron through Georgian Bay directly from Lake Ontario via the Trent RiverTrent Canal-Lake Simcoe-Severn River waterway, rather than by way of the Detroit River and Lake St. Clair, since the species had not been reported from the last two areas. In response to my query regarding this possibility, Dr. W. B. Scott wrote (Jan. 2, 1957) that there are no records of this species (or of Pelromyzon, Osmerus or Anguilla) from Lake Simcoe, or any other major portion of the waterway, even though the habitat there seems to be excellent for all of these fishes. The proposed route is a very involved, even tortuous one, and the water flows through hydroelectric plants at two marine railways at the western end of the system. Failure to take alewives in Detroit River is not surprising, since organized collecting there (as by the Michigan Institute for Fisheries Research) has been carried out chiefly in shallower waters than those which the alewife habitually seeks. Radforth (1944, pp. 95-96) also concluded that the alewife reached Lake Huron via the Detroit River and Lake St. Clair.

It seems evident that the alewife will become increasingly abundant in the Great Lakes and that utilization of this new resource should be encouraged. The species may well establish itself, by distribution in bait buckets, in such inland lakes as Crystal Lake, Benzie County, Michigan.

$\overline{1} \mathrm{O} n \overline{\mathrm{July}} 6,1956$, an alewife $139 \mathrm{~mm}$. S.L. was taken by I. A. Rodeheffer and J. K. Day in Mullet Lake, Cheboygan Co., Michigan (specimen in UMMZ collection). 
According to Robert Heffner, bait dealer from Beulah, it occurs nearby in Betsie River, near Frankfort, and at the mouth of Platte River; he has observed dense schools of alewives at sizes up to 4 inches at Frankfort. Although they do not survive well when collected in large numbers, a few do live and it is difficult to sort them all out from bait species. Alewives have been used in Lake Ontario as a ready source of cheap food as well as for fertilizer, and on the Atlantic coast they are marketed fresh, smoked or pickled.

\section{GIZZARD SHAD}

Discussion regarding the northern limit of this species, both for the Atlantic seaboard and for the Great Lakes-St. Lawrence basins, has been frequently published. Early errors in range statements and evidently in identification have led to subsequent confusion. Some of the controversy, however, also hinges on the question of whether Dorosoma is native in the Great Lakes drainage.

At least as early as the 1870's, Gill (1873, p. 811) erred by including Cape Cod in the distribution of this species. Subsequently, Jordan and Gilbert $(1883$, p. 271$)$ and others perpetuated the error. The author has been unable to discover the basis for listing Cape Cod as the northern limit of the gizzard shad on the Atlantic seaboard, but the locality has persisted in the literature almost to the present (e.g., see Vladykov, 1945, p. 36). D. cepedianum is uncommon north of latitude $40^{\circ} \mathrm{N}$. in New Jersey and southeastern Pennsylvania, and reaches its northern coastal limit in New York Harbor, usually called the Lower Bay or Sandy Hook Bay (Breder and Nigrelli, 1934, p. 194; Breder, 1938, pp. 23, 28). Halkett (1913, p. 46) stated that this species has been recorded from St. John River, Fredericton, New Brunswick, and this formed the basis of the inclusion of New Brunswick in the range of Dorosoma cepedianum by Hubbs and Lagler (1947, p. 34) and by Radforth (1944, p. 58). As pointed out by Vladykov (op. cit.), the New Brunswick record is based upon the remarks of an unknown author, who, in a review of Nash's Check List of the Fishes of Ontario, wrote of D. cepedianum: " . . . it is a native Canadian fish, and was recorded by the late Edward Jack on the St. John River, at Fredericton, N. B. . . ." The St. John River is a tributary of the Bay of Fundy and its mouth lies more than 500 miles northeast of the northernmost known coastal limit of Dorosoma. This record is therefore unacceptable; the fish thought to have been a gizzard shad very likely was the alewife, which occurs as far north as Newfoundland and has been confused with the gizzard shad.

Kirtland (1850, p. 2) appears to have been the first to suggest that Dorosoma entered the Great Lakes (i.e., Lake Erie) via canal connections, and this belief has been variously accepted and restated by subsequent authors during the succeeding century. The problem is complicated by the 
very different physical conditions of Lake Michigan and Lake Erie, the only two of the Great Lakes which offered direct access to the gizzard shad in glacial or postglacial times. More than a dozen species, representing three families, show a distributional pattern in Michigan that clearly indicates penetration from the south into southeastern Michigan. These fishes invaded the Lake Erie basin by utilizing the former outlet (now Maumee River) of the glacial precursor of Lake Erie, or by way of other natural connections across the very low divide between that basin and the Mississippi River system. Yet not one of these species is known from the adjacent drainage of Lake Michigan. It seems evident that the colder, deeper water of that lake has served as an effective barrier to these fishes, as it evidently has, until very recently, to the gizzard shad. Thus, although this species was reported by Nelson $(1876$, p. 44) from the Chicago River canal and Lake Michigan, there is no objective evidence to show that the gizzard shad established itself in the lake by migration from the Illinois River until recent years. There are no specimens of this species from the southern tip of Lake Michigan in the Chicago Natural History Museum (or any cther collection), and Forbes and Richardson (1919, Map 8) gave no records nearer Lake Michigan than the junction of Fox and Illinois Rivers in La Salle County, Illinois; furthermore, Gerking (1945, Map 8) did not find it in the Lake Michigan drainage of Indiana.

Whether Dorosoma is native to Lake Erie cannot be solved conclusively because, to the author's knowledge, there are neither specimens nor records of gizzard shad from this lake prior to the completion in 1830 of the first canal connecting the Ohio River with Lake Erie. The first specimens of Dorosoma to be reported from the Great Lakes were four fish recorded by Kirtland (loc. cit.) in November, 1848, from near the mouth of the Cuyahoga River at Cleveland. He was certain that this species did not occur in Lake Erie or its tributaries in 1840, and believed the specimens captured in 1848 represented recent invaders from the south. Kirtland was perhaps overimpressed by the winterkill of many gizzard shad during a hard freeze in the Dayton Canal, since he cited this as evidence that Dorosoma "was a native of a warmer climate." He was also impressed with the failure of fishermen to recognize the gizzard shad near Cincinnati much before 1840 and with their stated belief that it was an emigrant from the south. Klippert (in Jordan, 1882, pp. 870-871) also believed that the gizzard shad was not native to Lake Erie; he wrote that "before the construction of the Ohio Canal it was not found anywhere north of the divide, or water shed between the lake [Erie] and the Ohio River." According to Jordan (op. cit., p. 742), Mr John H. Klippert was "a close observer and excellent amateur ichthyologist."

In November, 1877, Samuel Wilmot (1879) collected a specimen of $D$. cepedianum from Sarnia, Ontario, at the southern tip of Lake Huron. It was identified by Baird as Dorosonia cepedianum beterurum and the author has verified that it is a gizzard shad (USNM No. 20836). In transmitting 
this specimen, Wilmot wrote that "Fish very similar in appearance to this one have been known in Lake Ontario and other of our waters for many years; I recollect them forty years ago." This would have been about 1837. Wilmot was a pioneer fish culturist and supervisor of the Canadian salmon hatchery at Newcastle on Lake Ontario (Milner, 1874, pp. 25, 58, 228, 231), and he surely knew the American shad; his testimony strongly sug. gests that the gizzard shad inhabited the Lake Ontario basin as early as 1837, although it is possible that the species he referred to may have been the alewife. The first published record of the gizzard shad in Lake Ontario that I have noted is for 1913, when Nash reported the species to be very rare (see Dymond, Hart and Pritchard, 1929, p. 14). Since it is now known from an actual specimen that Dorosoma occurred in Lake Huron in the 1870 's, it seems obvious that the reference by Milner (1874, p. 36) to the "saw-belly," identified as Pomolobus chrysochloris Rafinesque, actually represents one of the early records of Dorosoma cepedianum from the Great Lakes (which lake was not specified). This conclusion was first expressed by Hubbs and Lagler (1947, footnote, p. 34).

Although the possibility that Dorosoma first entered Lake Erie through canals cannot be ruled out, it is perhaps more plausible to regard this species as a postglacial migrant into Lake Erie. This view is favored by Trautman (1957). On the northern fringe of its range Dorosoma is near the limit of its thermal tolerance, forging northward during a series of favorable years and then, under adverse conditions, becoming almost eliminated (see, for example, Cox, 1896, p. 610). When numbers are killed and fishermen see the species for the first time, they fail to recognize it and conclude that it is a recent invader from a more southern clime. Dr. Trautman wrote me that this has happened innumerable times in Ohio since Kirtland's day. Perhaps the gizzard shad gained access to Lake Erie during a warm-dry period in pre-Columbian times and then, with the retrun to present conditions, it retreated but left relict populations. Dorosoma is favored to establish outlying colonies because spawning adults enter small streams or ditches, provided they are of low gradient, and the young are later abundant there. In early historic time, there were many places along the divide between the Ohio and Lake Erie watersheds (e.g., the close approach of the Maumee and Wabash drainages near Ft. Wayne, (Indiana) where Dorosoma could readily have crossed from one drainage to the other. It is also possible, as Gerking (1945, p. 33) suggested, that the gizzard shad may have entered the glacial precursor of Lake Erie through the Ft. Wayne outlet (Maumee River), but this view seems less acceptable because Dorosoma does not appear to be adapted to very cold water, such as prevailed during the melting of the continental glaciers in the evolution of the Great Lakes. The species occurs in the Great Lakes drainage of Indiana only in the Maumee River system (Gerking, op. cit., Map 8). There appears to be no need for nor support of the hypothesis (Radforth, loc. cit.) that Dorosoma utilized the Mohawk-Hudson glacial 
outlet (or the Chicago-Ubly outlet) to enter Ontario; if it uilized glacial waterways at all, the Maumee outlet seems to be the only possible one that it might have entered. Vladykov (op. cit.) concluded that this species reached the environs of Quebec by descending the St. Lawrence River from the Great Lakes.

Thus the gizzard shad, as perhaps with the alewife in Lake Ontario, apparently neared the limit of its tolerance in Lake Erie. Its increase and spread in the lower Lakes may well reflect the known warming climatic trend (Baum and Havens, 1956) or may be a response to changing biotic conditions of the Great Lakes in recent decades - or both phenomena may be operative. That the species has entered canals and thus extended its range seems well founded (e.g., see Wright, 1918, p. 544; Greeley, 1928, p. 95).

The first valid records (based on identified, preserved specimens) of Dorsoma cepedianum from Lake Michigan are the following: UMMZ No. 165645 , an adult, $255 \mathrm{~mm}$. S. L., taken by the McNab brothers, on October 13, 1953, in a trap net in 14 feet of water about 1 mile south of the channel connecting Lake Michigan and Muskegon Lake, west of Muskegon, Michigan. A second specimen, an immature female in poor condition identified by the author and then discarded, was obtained by D. C. Erlandson from a pound net set in 25 feet of water, on November 2, 1953, off Miller, 5 miles east of Gary, Indiana. The evidence clearly points to a southern origin for these stocks, since no specimens have been reported in the northern half of Lake Michigan or in northwestern Lake Huron. Dorosoma has thus gradually extended its range into Lake Huron by emigration from Lake Erie and into Lake Michigan through the Chicago River Canal. The gizzard shad has not been reported from Lake Superior, where low temperature and the absence of shallow water may preclude its establishment.

This species has had a long history of fluctuating abundance in Lake Erie but it evidently has rather recently established itself in numbers in certain parts of Lake Huron. For example, Bensley (1915) did not record it from Georgian Bay, and when Walter Koelz collected a specimen there late in 1919 (UMMZ No. 55632), fishermen informed him that the gizzard shad had rather recently appeared and that all those taken were small. Today the species is fairly common in suitable parts of Georgian Bay. It was so abundant in Detroit River and Lake St. Clair in the fall of 1932 that unemployed persons caught them for food with dipnets and hook and line. By October 7, 1933, the gizzard shad had moved inland up the Saginaw River drainage as far as Pine River at St. Louis, Gratiot Co., Michigan (UMMZ No. 101607, 1 adult); this is one of the few records of its occurrence well inland from the Great Lakes and populations have not established themselves at appreciable distances inland. An attempt was made to establish the species in Whitmore Lake, Washtenaw and Livingston Counties, Michigan, in August, 1935, when the Michigan Institute for Fisheries Research stocked 124 individuals ( 1.5 to 15.0 inches S. L.) 
from Lake St. Mary's, Ohio. It is estimated that 100 adult shad survived after one week, but if so, successful reproduction did not occur and the intrcduction failed (IFR Report No. 315; see also Cooper and Schafer, 1954).

Abundance in lakes Erie and Huron since about 1940 is indicated by the commercial catch statistics (U. S. Fish and Wildlife Service and Michigan Department of Conservation) which show that a total of approximately 116,000 pounds valued at $\$ 2,300$ were taken during the period from 1942 to 1954. The largest catch for a single year, 31,600 pounds valued at $\$ 930$, was taken in 1949 . Occasionally, sudden mortality of vast numbers (similar to that of the alewife in Lake Ontario) creates a public nuisance, as it did at Erie, Pennsylvania, during January-February, 1953. (This and other aspects of the biology of the gizzard shad are summarized by me in a paper to be published by the U. S. Fish and Wildlife Service entitled: "The clupeid fishes of the subfamily Dorosomatinae, with special reference to the gizzard shad, Dorosoma cepedianum.")

The gizzard shad is not as widespread in the Great Lakes as the alewife, probably because its preferred habitat is less extensive, and, except locally, it is not likey to attain or exceed the popuation size of that species. It has been utilized in the Great Lakes as a source of food for trout, swine and cattle, as fertilizer, and it has been steamed and pressed for oil.

\section{ACKNOWI.EDGMENTS}

Splendid cooperation from many soulces has made this paper posible. I have tried to recognize individually the valuable help given by fishermen by mentioning them in the text. The Institute of Fisheries Research of the Michigan Department of Conservation has kept me informed of new records; Gerald P. Cooper, Kivoshi G. Fukano, Walter R. Crowe, Stanley Lievense, Leland R. Anderson, and T. $H$. Durling have been especially helpful. The staff of the U.S. Fish and Wildlife Service's Great Lake Laboratory, particularly James W. Moffett, Ralph Hile, Stanford H. Smith, and Leonard S. Joeris, have made available pertinent records and have discussed critical aspects of the manuscript. Raymond E. Johnson and John G. Hale have supplied Minnesota records. John Van Oosten has been of great help with literature references. Milton B. Trautman has given me the benefit of his long experience with the alewife and gizzard shad in Lake Erie and has generously allowed me to draw from material in press. My colleagie, Reeve $M$. Bailey, has critically read the manuscript and offered valuable suggestions. A number of Canadian workers, especially W. B. Scott, F. E. J. Fry. John Budd. J. Murray Speirs, Richard A. Ryder, and Kenneth $H$. Loftus, have filled in records for the Canadian portion of the Great Lakes, and Di: Scott has provided stimulating discussion and useful references relating to the origin and dispersal of the alewife. All of these people have my grateful thanks.

\section{Literature Cited}

Bailey, Rfeve M., Howard Ellott Winn, and C. Lavett Smith 1954. Fishes from the Escambia River, Alabama and Florida, with ecologic and taxonomic notes. Prcc. Acad. Nat. Sci. Phila., Vol. 106, pp. 109-164. 
Baum, Werner A., and James M. Havens

1956. Recent climatic fluctuations in maritime provinces. Trans. 21st N. Amer. Wildlife Conf., pp. 436-453.

Bean, TaRleton H.

1884. On the occurrence of the branch alewife in certain lakes of New York. In: Goode, George Brown. The fisheries and fishery industries of the United States. Sec. I, text, pp. 588-593.

BENSLEY, B. A.

1915. The fishes of Georgian Bay. Contrib. Canad. Biol., 1911.1914, Fasc. 2, pp. $1-51$.

Breder, Charles M., Jr.

1938. The species of fish in New York harbor. Bull. N.Y. Zool. Soc., Vol. 41, pp. 23-29, 3 figs.

BReder, C. M., Jr., and Ross Nigrelir

1934. Fish notes for 1933 and 1934 from Sandy Hook Bay and other New York localities. Copeia, 1934, No. 4, pp. 193-195.

Cooper, Gerald P., and Robert N. SChafer

1954. Studies on the population of legal-size fish in Whitmore Lake, Washtenaw and Livingston Counties, Michigan. Trans. 19th N. Amer. Wildlife Conf,, Pp 239-259, fig. 1

CoX, Uiysses O.

1896. A report on the fishes of southwestern Minnesota. Rept. U.S. Comm. Fish and Fish., Pt. 20 (1894), Pp. 605-616.

DYMOND, JOHN R.

1932. Records of the alewife and steelhead (rainbow) trout from Lake Erie. Copeia, 1932, No. 1, p. 32.

Dymond, J. R., J. L.HART, and A. L. Pritchard

1929. The fishes of the Canadian waters of Lake Ontario. Univ. Toronto Studies. Publ. Ontario Fish. Res. Lab., No. 37, pp. 1-35.

EvermanN, Barton Warren, and William C. Kendali

1902. Notes on the fishes of Lake Ontario. Rept. U.S. Comm. Fish., 1901, PP 209-216.

Forbes, Stephen Alfred, and Robert Earl Richardson

1919. Maps showing distribution of Illinois fishes to accompany a report on the fishes of Illinois. Ed. 2. III. Nat. Hist. Surv., Atlas, 103 maps.

Gerking, Sheiby D.

1945. The distribution of the fishes of Indiana. Inv. Ind. Lakes and Streams, Vol. 3, No. 1, Pp. 1-137, Maps 1-113.

GILL, THEODORE

1873. Catalogue of the fishes of the east coast of North America. Rept. U.S. Comm. Fish and Fish., 1871-72, Pt. 1, pp. 779-822.

Graham, I. J.

1956. Observations on the alewife, Pomolobus pseudobarengus (Wilson), in fresh water. Publ. Ontario Fish. Res. Lab., No. 74 (Univ. Toronto Biol. Ser. No. 62), pp. $1-43$, figs. $1-20$.

GREeLEY. T. R.

1928. Fishes of the Oswego watershed. N. Y. Conserv. Dept., Suppl. 17th Ann. Rept., 1927, pp. 84-107, col. pls. 1-12.

HALKETT. ANDREW

1913. Check list of the fishes of the Dominion of Canada and Newfoundland. Ottawa, pp. 1-138, pls. 1-14.

Hildebrand. Samuet. F.. and William C. Schroeder

1928. Fishes of Chesapeake Bay. Bull. U.S. Bur. Fish., Vol. 43 (1), pp. 1-366, illus. 
Hubbs, Cari L., and Karl F. Lagier

1947. Fishes of the Great Lakes region. Cranbrook Inst. Sci., Bull. 26, pp. xi + 186 , illus.

JORDAN, DAVID S.

1882. Report on the fishes of Ohio. Ohio Geol. Surv., Vol. 4, Pt. 1, pp. 737-1,002.

Jordan, David S., and Charles H. Gilbert

1883. Synopsis of the fishes of North America. U.S. Nat. Mus., Bull 16, pp. i-lvi, $1-1,018$.

Kirtland, J. P.

1850. Fishes of Ohio. Fragments of natural history. The Family Visitor, Cleveland [and Hudson], Vol. 1, No. 1, pp. 1-2 (Jan. 3, 1850).

Langlois, Thomas $\mathrm{H}$.

1954. The western end of Lake Erie and its ecology. J. W. Edwards, Inc., Ann Arbor, Mich. 479 pp., illus.

LEIM, A. $H$.

1924. The life history of the shad Alosa rapidissima (Wilson), with special reference to the factors limiting its abundance. Contr. Canadian Biol., n. s., Vol. 2, pp. 161-284.

MACKAY, H. H.

1934. Record of the alewife from Lake Huron. Copeia, 1934, No. 2, p. 97.

MILLER, ROBERT RUSH

1950. A review of the American clupeid fishes of the genus Dorosoma. Proc. U.S. Nat. Mus., Vol. 100, pp. 387-410.

Milner, James W.

1874. Report on the fisheries of the Great Lakes; the results of inquiries prosecuted in 1871 and 1872. Rept. U.S. Comm. Fish and Fish., 1872-73, App. A, pp. $1-75$.

NeLSON, E. W

1876. A partial catalogue of the fishes of Illinois. Bull. Ill. Mus. Nat. Hist., Vol. 1, pp. 33-52.

RADFORTH, ISOBEL

1944. Some considerations on the distribution of fishes in Ontario. Contrib. Roy. Ontario Mus. Zool., No. 25, pp. 1-116, fig. 1-32.

SMITH, HUGH $M$.

1892. Report on an investigation of the fisheries of Lake Ontario. Bull. U.S. Fish Comm., Vol. 10 (1890), pp. 177.215 pls. 21-50.

TONER, G. C.

1934. Notes on the alewife. Canadian Field-Nat., Vol. 48, pp. 51-52.

Trautman, Milton B.

1957. The fishes of Ohio. Ohio State Univ. (in press).

VAN OOSTEN, JohN

1935. 'First record of the alewife, Pomolobur preudo-batengus, for the state of Michigan. Copeia, 1935, No. 4, pp. 194-195.

VLADYKOV, VADIM D.

1945. Trois poissons nouveaux pour la province de Quebec. Canadian Nat., Vol. 72, pp. 27-39, 5 figs.

VLanYKov. V. D., and D. H. Wali.are

1938. Populations of the shad (Alosa sapidissima) along the Atlantic Coast region. Trans. Amer. Fish. Soc., Vol. 67 (1937), pp. 52-66.

Wilmot, SAMUel

1879. Notes on the western gizzard shad, Dorosoma cepedianum heferurum (Raf.) Jordan. Proc. U.S. Nat. Mus., Vol. 1, pp. 263-264.

Wright, Albert Hazen

1918. Fish succession in some Lake Ontario tributaries. Sci. Mon., Vol. 7, pp. 535-544, maps 1.3 . 